\title{
Anti-Inflammatory Effects of Chamaecyparis Obtusa Essential Oil on Peripheral Blood Mononuclear Cells
}

\author{
Seung-Heon Shin, Young-Do Jung, Youn-Tae Seo, Ho-Jin Son, and Mi-Kyung Ye \\ Department of Otolaryngology-Head and Neck Surgery, School of Medicine, Catholic University of Daegu, Daegu, Korea \\ 말초혈액 단핵구 활성화에 대한 편백정유의 항염증 작용 \\ 신승헌 · 정영도 · 서윤태 · 손호진 · 예미경 \\ 대구가톨릭대학교 의과대학 이비인후과학교실
}

Received May 24, 2017

Revised August 1, 2017

Accepted August 7, 2017

Address for correspondence

Seung-Heon Shin, MD, PhD

Department of Otolaryngology-

Head and Neck Surgery,

School of Medicine,

Catholic University of Daegu,

33 Duryugongwon-ro 17-gil,

Nam-gu, Daegu 42472, Korea

Tel $+82-53-650-4530$

Fax $+82-53-650-4533$

E-mail hsseung@cu.ac.kr
Background and Objectives The biological activity in antibacterial and antioxidative action of essential oils (EOs) have been investigated. In this study, we tried to evaluate the effects of Chamaecyparis obtusa EOs on producing chemical mediators by peripheral blood mononuclear cells (PBMCs).

Subjects and Method PBMCs from healthy volunteers were stimulated with lipopolysaccharide (LPS) and phytohaemagglutinin (PHA) in the presence of varying concentrations of EOs. Cytotoxic effects of EOs were measured using an aqueous cell proliferation assay kit and supernatants were analyzed using enzyme-linked immunosorbent assay. Tumor necrosis factor- $\alpha$ (TNF- $\alpha$ ), interleukin-5, and interferon- $\gamma(\mathrm{INF}-\gamma)$ protein levels were measured to determine the anti-inflammatory effects of essential oil.

Results EOs were found to have cytotoxic effects on PBMCs at levels of over 1\%. EOs not only could induce PBMCs to produce chemical mediators, but it also significantly inhibited the LPS induced TNF- $\alpha$ and INF- $\gamma$ productions as well as the PHA induced INF- $\gamma$ production. Conclusion EOs had cytotoxic effects at high concentrations and modulated chemical mediator productions from PBMC. These data suggest that EOs could be used to treat immunologic or inflammatory diseases. Korean J Otorhinolaryngol-Head Neck Surg 2017;60(11):565-9

Key Words Anti-inflammation · Chamaecyparis obtusa · Essential oil · Peripheral blood mononuclear cell.

\section{서 론}

피톤치드로 알려진 나무정유는 수목들이 주위의 해충이나 미생물로부터 자신을 방어하기 위해 공기 중 또는 땅 속에 발 산하는 무독성의 휘발성 방향 물질을 총칭한다. Phenolics, terpenoid, alkaloid, phenylpropane, acetogenin 등의 화합 물로 구성되어 있으며 항세균, 항진균 등의 항균력을 가지고 있다. ${ }^{1-5)}$ 최근 삶의 질에 대한 관심이 높아지면서 천연물질의

This is an Open Access article distributed under the terms of the Creative Commons Attribution Non-Commercial License (http://creativecommons.org/licenses/by-nc/4.0) which permits unrestricted non-commercial use, distribution, and reproduction in any medium, provided the original work is properly cited.
가치와 활용도에 대한 관심이 증가되었고 건강 보조제, 화장 품, 방향제, 향기치료 등 다양한 분야에서 나무정유가 사용 되고 있다. ${ }^{67)}$ 편백나무, 구상나무, 화백나무, 삼나무 등이 계 절에 상관없이 많은 양의 나무정유를 분비하며 특히 편백정 유는 이들 중 가장 많은 나무정유를 함유하고 있다. 편백나 무는 아열대성 식물로 국내에서는 남해안 지역에 군락지가 분포하고 있으며 국내에서도 항균, 항진균 효과 등에 대한 다 양한 연구가 이루어져 왔다. ${ }^{8-10)}$ 편백정유의 경우 일본과 대만 지역에서 많은 연구가 이루어져 왔으며 지역에 따라 정유의 구 성 성분에 차이가 있어 최근에 국내 연구가 진행되기 시작하 면서 다양한 영역에서의 효과가 입증, 활용되고 있다.,11) 
림프구는 알레르기 및 감염성 염증반응에 관여하는 면역 조절 세포로 다양한 화학매개물질을 만들어 다른 염증세포 와 염증조직의 면역반응에 영향을 미친다. ${ }^{12)}$ 즉 림프구에서 만 들어지는 화학매개물질에 의해 면역기능이 시작, 유지, 조절되 며 이들 화학매개물질 생성의 관리는 염증반응을 억제할 수 있는 중요한 치료 수단이 될 수 있다. 말초혈액 단핵구는 림 프구, 단핵구, 수상세포 등으로 구성되어 있으며, 이들 염증세 포에서 만들어지는 화학매개물질에 의해 염증성 면역반응이 조절되고 있어 이들 화학매개물질의 조절이 염증성 질환의 치료에 중요한 역할을 담당할 것이다. 화학매개물질의 생성 을 억제하는 다양한 물질이 사용되고 있으며 나무정유 또한 염증세포의 화학매개물질을 억제하여 항염증 효과를 가지는 것으로 알려져 있다. ${ }^{13,14)}$

본 연구는 국내에서 생산된 편백정유를 이용하여 말초혈 액 단핵구의 활성화 과정에서 만들어지는 화학매개물질의 생성에 미치는 영향을 확인함으로써 편백정유의 항염증 치 료제로서의 활용 가능성을 확인하고자 하였다.

\section{대상 및 방법}

\section{말초혈액 단핵구의 분리 및 활성화}

말초혈액 단핵구는 감염성 혹은 알레르기성 질환이 없으면 서, 최근 4주 이내 항생제, 항히스타민제 등의 약물 투여를 받 지 않은 25 45세의 건강한 성인 남자 7명, 여자 3명의 말초혈 액에서 분리하였으며, 참여한 모든 대상자의 동의를 받았다. 연구는 대구가톨릭대학교병원 임상시험 윤리 위원회의 검토 와 승인을 얻은 후 진행하였다(CR-14-070).

말초혈액 단핵구는 헤파린 처리된 혈액을 density gradient centrifugation 법을 이용하여 분리하였다. 말초혈액 단핵구 $2 \times 10^{6} / \mathrm{mL}$ 를 $10 \%$ calf serum, 2 umol/L glutamine, $50 \mathrm{umol} / \mathrm{L}$ 2-mercaptoethanol이 섞인 RPMI-1640을 이용하여 $37^{\circ} \mathrm{C}$, $5 \% \mathrm{CO}_{2}$ 에서 배양하였다. 이때 말초혈액 단핵구와 함께 $5 \mathrm{ug} /$ $\mathrm{mL}$ 의 phytohaemagglutinin(PHA: Life Technologies, Grand Island, NY, USA)과 $10 \mathrm{ug} / \mathrm{mL}$ 의 lipopolysaccharide (LPS: Sigma, St. Louis, MO, USA)를 넣고 8, 24, 48, 72시 간 배양 후 상층액을 얻어 tumor necrosis factor- $\alpha(\mathrm{TNF}-\alpha)$, Interleukin-5(IL-5), interferon- $\gamma(\mathrm{INF}-\gamma)$ 를 효소면역측정 법을 이용하여 측정하였다(Endogen, Wobrun, MA, USA). $\mathrm{TNF}-\alpha, \mathrm{IL}-5, \mathrm{INF}-\gamma$ 모두 $2 \mathrm{pg} / \mathrm{mL}$ 이상의 민감도를 가지 고 있었다.

편백정유는 편백나무의 잔가지와 잎을 고온 스팀 처리 후 응 축시킨 정유를 큐웰사(Seoul, Korea)에서 제공받아 사용하였 다. 편백정유의 세포독성을 확인하기 위하여 편백정유 0.05 ,
$0.1,0.2,1 \%$ 를 말초혈액 단핵구와 함께 $8,24,48,72$ 시간 동안 배양 후 Promega사(Madison, WI, USA)의 CellTiter-96 ${ }^{\circledR}$ aqueous cell proliferation assay 키트를 이용하여 세포증식 을 측정하였다. 검사 방법을 간단히 살펴보면, 배양된 말초혈 액 단핵구에 tetrazolium 합성물 $2 \mathrm{~mL}$ 와 phenazine ethosulfate $100 \mathrm{uL}$ 를 섞은 후 well당 $20 \mathrm{uL}$ 의 혼합용액을 첨가하 여 1시간 동안 배양 후 $490 \mathrm{~nm}$ 의 ELISA reader(Modecular Devices, Sunnyvale, CA, USA)를 사용하여 흡광도를 측정 하였다.

편백정유의 항염증 효과는 말초혈액 단핵구에 $5 \mathrm{ug} / \mathrm{mL}$ 의 PHA 혹은 $10 \mathrm{ug} / \mathrm{mL}$ 의 LPS와 함께 편백정유 0.05, 0.1, $0.2 \%$ 를 넣고 $8,24,48,72$ 시간 배양 후 상층액을 얻어 $\mathrm{TNF}-$ $\alpha, \mathrm{IL}-5, \mathrm{INF}-\gamma$ 를 측정하여 비교하였다.

\section{통계분석}

실험은 최소 5 회 이상 반복하여 시행하였으며 얻어진 결과는 평균 \pm 표준편차로 표기하였다. 말초혈액 단핵구의 세포독성은 Mann-Whitney U test를 이용하여 비교하였고, 편백정유의 항 염증 효과는 Wilcoxon matched paired test를 이용하여 비교 하였다(SPSS ver. 21.0, IBM Corp., Armonk, NY, USA).

\section{결 과}

다양한 농도의 편백정유와 함께 말초혈액 단핵구를 8, 24, 48,72 시간 배양하였을 때 $1 \%$ 편백정유로 말초혈액 단핵구를 처리한 경우 배양 시간에 관계없이 세포의 생존이 $50 \%$ 이상 감소함을 확인할 수 있었으나 그 이하의 농도에서는 세포독 성을 보이지 않았으며 $0.05 \%$ 의 낮은 농도에서는 세포 증식이 증가하는 양상을 보여 이후 연구는 $0.2 \%$ 이하의 농도에서 실

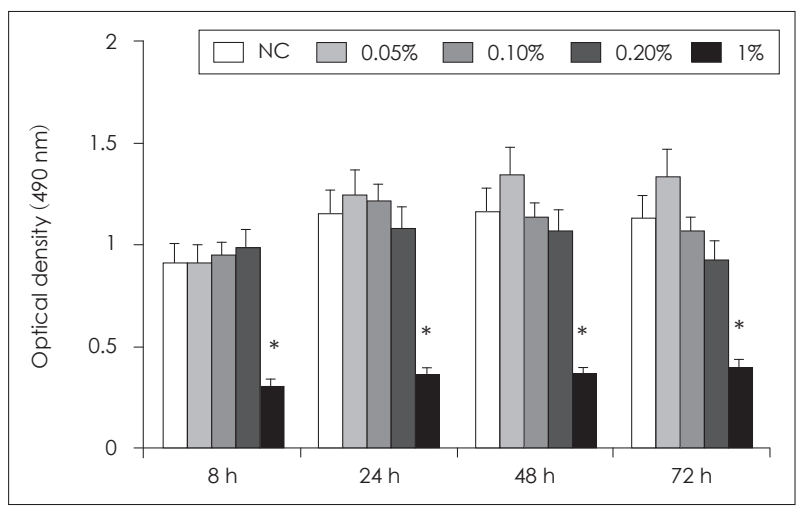

Fig. 1. Cytotoxic effect of Chamaecyparis obtusa essential oil on PBMCs at variaious concentraions with CellTiter- $96^{\circledR}$ aqueous cell proliferation assay. PBMCs from five healthy individuals were treated with essential oil for 72 hours. Essential oil at concentration over $1 \%$ decreased cell proliferation. ${ }^{*} p<0.05$ vs. NC. PBMCs: peripheral blood mononuclear cells, NC: negative control. 
험을 진행하였다(Fig. 1).

편백정유가 말초혈액 단핵구의 활성화에 미치는 영향을 확인하기 위하여 말초혈액 단핵구와 다양한 농도의 편백정 유를 $8,24,48,72$ 시간 배양하였을 때 $\mathrm{TNF}-\alpha$ 의 경우 배양 48시간에 편백정유 $0.05 \%(129.5 \pm 43.2 \mathrm{pg} / \mathrm{mL})$ 와 $0.1 \%(90.0$

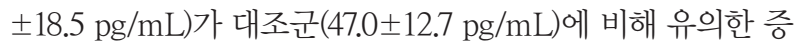
가 소견을 보였으며, INF- $\gamma$ 의 경우는 배양 24 시간과 72 시간
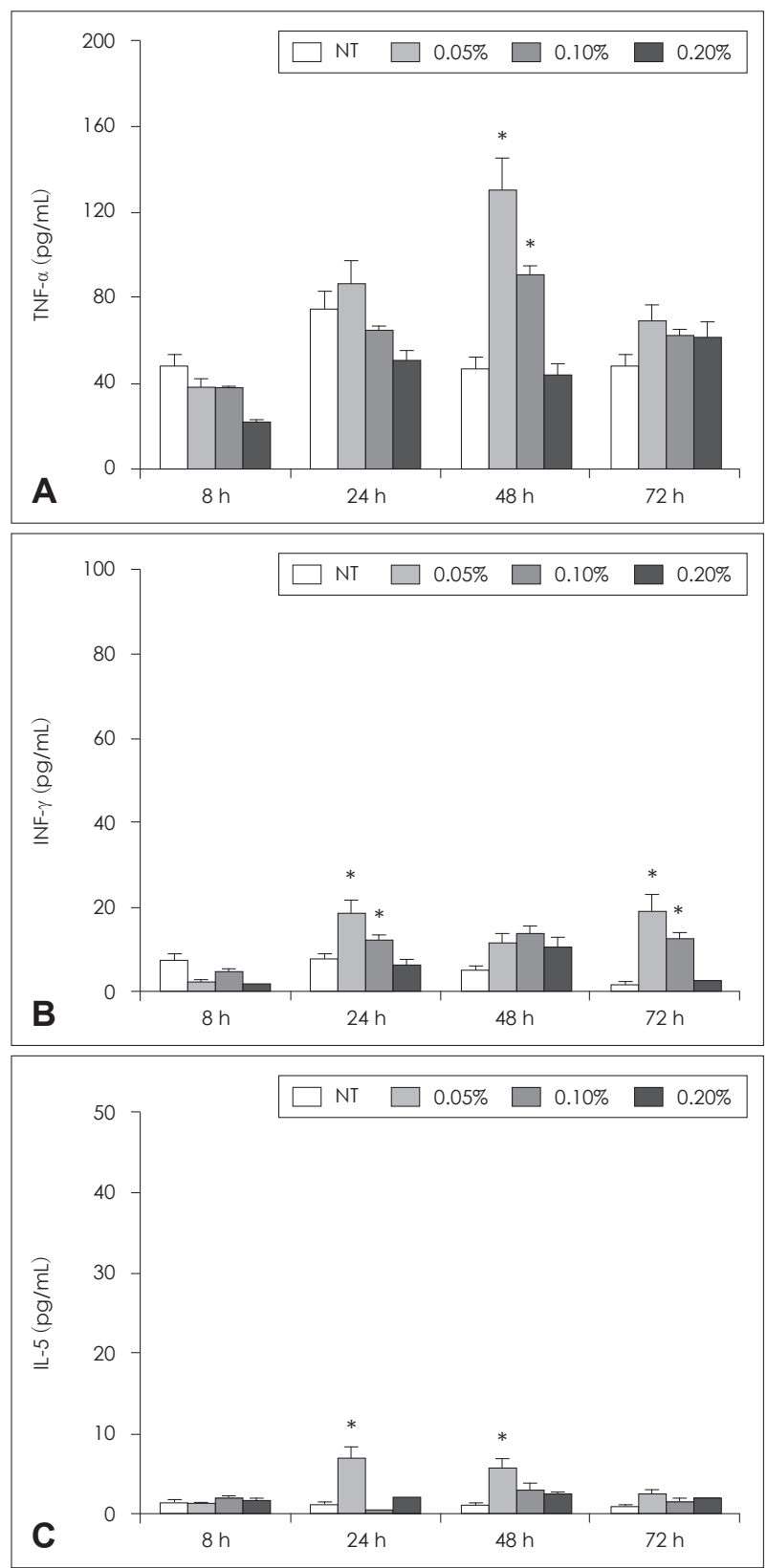

Fig. 2. Influence of Chamaecyparis obtusa EO on cytokine production by peripheral blood mononuclear cells. $0.05 \%$ and $0.1 \%$ of EO enhanced TNF- $\alpha$ production at 48 hours (A). $0.05 \%$ and $0.1 \%$ of EO enhanced INF-y production at 24 hours (B). $0.05 \%$ of EO enhanced IL- 5 production at 24 and 48 hours (C). ${ }^{*} p<0.05$ vs. NT. EO: essential oil, TNF- $\alpha$ : tumor necrosis factor- $\alpha$, INF- $\gamma$ : interferon- $\gamma$, IL-5: interleukin-5, NT: non-treated group.
에 편백정유 $0.05 \%$ 와 $0.1 \%$ 에서 유의한 증가 소견을 보였으 며, IL-5의 경우는 배양 24시간과 48시간에 편백정유 $0.05 \%$ 에 의한 유의한 증가소견을 보였으나 $(p<0.05)$ 편백정유는 말 초혈액 단핵구의 INF- $\gamma$ 와 IL-5 생성에 강하게 영향을 미치

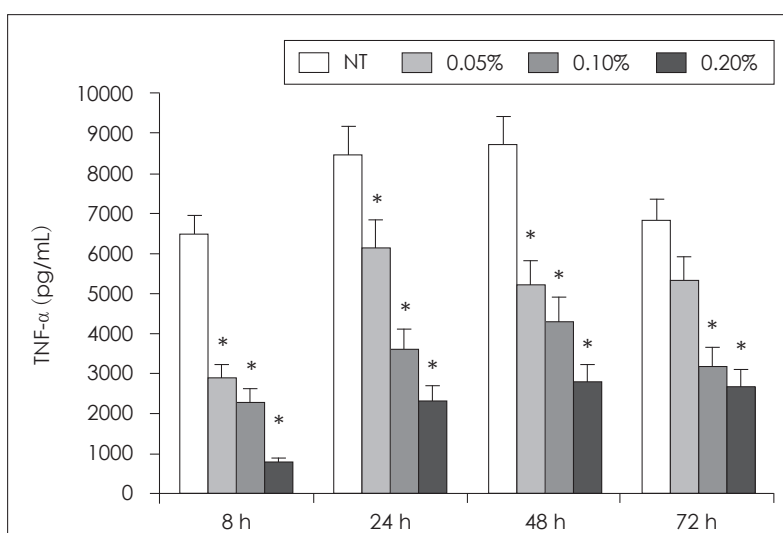

A

LPS $10 \mathrm{ug} / \mathrm{mL}+\mathrm{EO}$

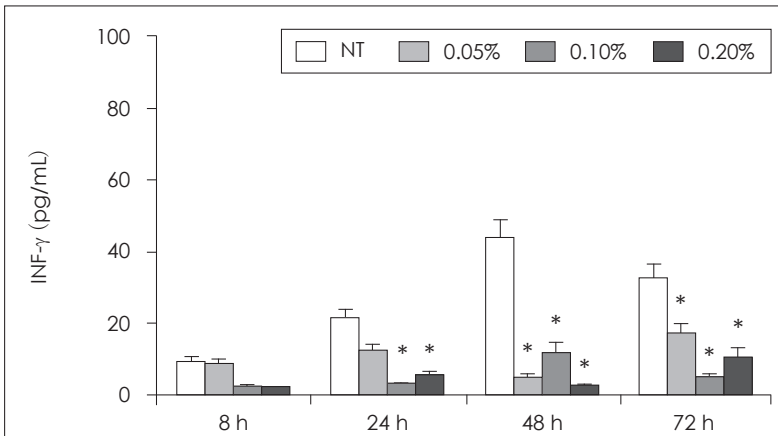

B

LPS $10 \mathrm{ug} / \mathrm{mL}+\mathrm{EO}$

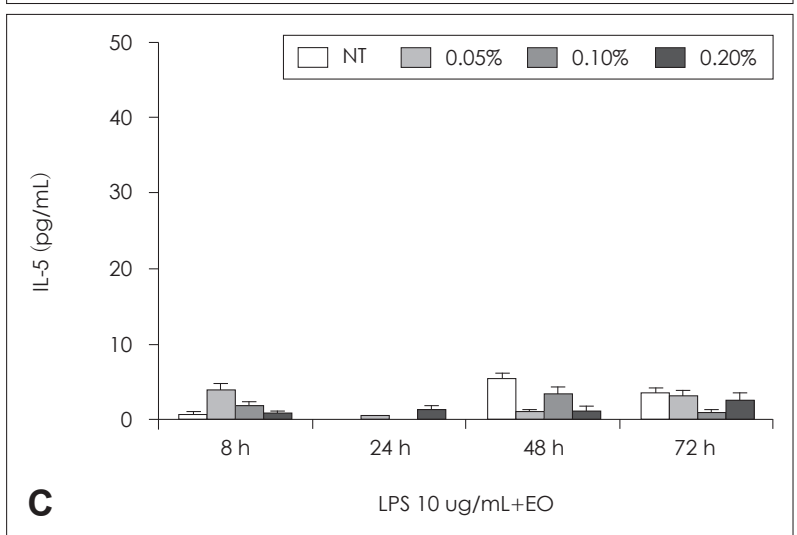

Fig. 3. Effect of Chamaecyparis obtusa EO on cytokine production by PBMCs. Cells were stimulated $10 \mathrm{ug} / \mathrm{mL}$ of LPS with various conentration of EOs. LPS induced TNF- $\alpha$ productions were significantly inhibited with $0.05,0.1$, and 0.2 of EO at 24,48 , and 72 hours (A). LPS induced INF-y productions were significantly inhibited with concentration over $0.05 \%$ of $E O$ at 24,48 , and 72 hours (B). LPS did not influence IL-5 production and EO also did not influence IL- 5 production of PBMCs (C). * $p<0.05$ vs. NT. EO: essential oil, PBMCs: peripheral blood mononuclear cells, LPS: lipopolysaccharide, TNF- $\alpha$ : tumor necrosis factor- $\alpha$, INF- $\gamma$ : interferon- $\gamma$, IL-5: interleukin-5, NT: non-treated group. 
지는 않았다(Fig. 2).

말초혈액 단핵구를 그람음성균의 세포벽 성분인 LPS로 활성화를 유도한 경우 LPS에 의한 $\mathrm{TNF}-\alpha$ 의 생성은 편백정 유 농도의 증가에 따라 배양 $8,24,48,72$ 시간 모두에서 유
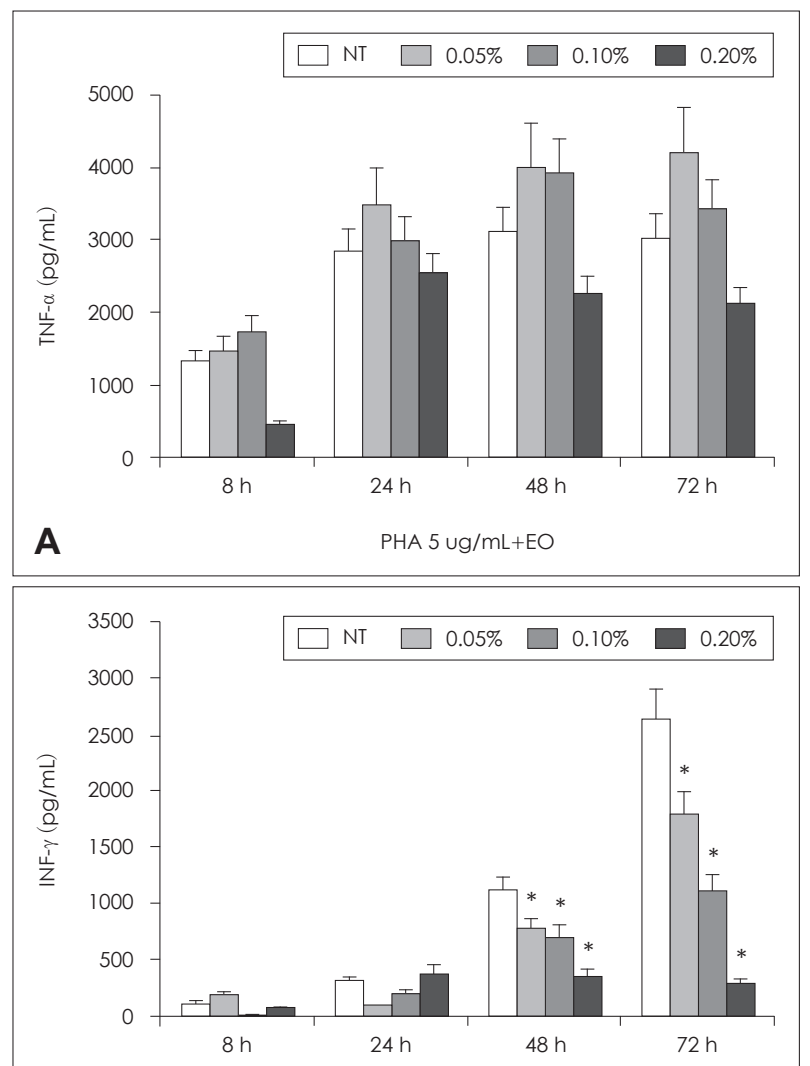

B

PHA 5 ug/mL+EO

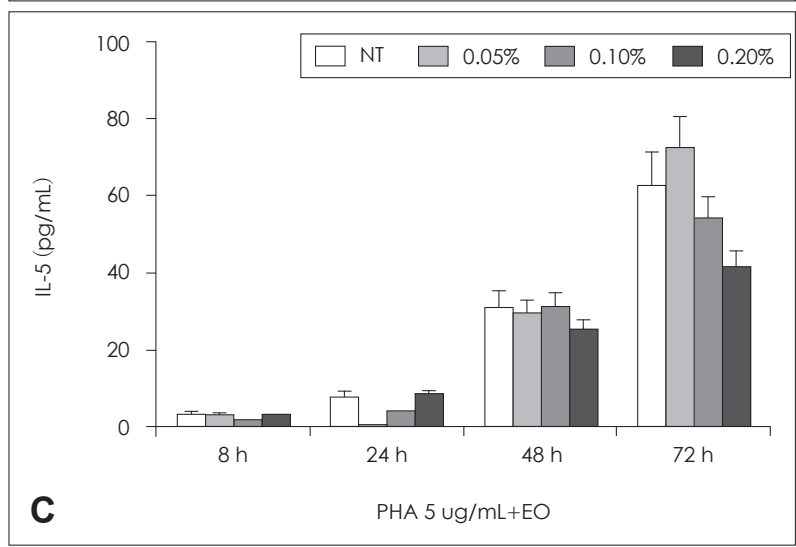

Fig. 4. Effect of Chamaecyparis obtusa EO on cytokine production by peripheral blood mononuclear cells. Cells were stimulated $5 \mathrm{ug} / \mathrm{mL}$ of PHA with various conentration of EOs. PHA induced TNF- $\alpha$ productions were not inhibited with various concentrations of EOs (A). PHA induced INF-y production were significantly inhibited at concentration over $0.05 \%$ of EOs at 48 and 72 hours incubation (B). PHA induced IL-5 productions tended to be inhibited with $0.2 \%$ of EO at 72 hours incubation, however it was not statistically significant (C). ${ }^{*} p<0.05$ vs. NT. EO: essential oil, PHA: phytohaemagglutinin, TNF- $\alpha$ : tumor necrosis factor- $\alpha$, INF- $\gamma$ : interferon-y, IL-5: interleukin-5, NT: non-treated group.
의하게 감소됨을 확인할 수 있었고, $\mathrm{INF}-\gamma$ 의 생성은 배양 24시간 이후부터 편백정유에 의해 유의하게 생성이 억제됨 을 확인할 수 있었다. 하지만 LPS는 말초혈액 단핵구의 IL-5 생성을 유도하지 못하였으며 편백정유 또한 IL-5의 생성에 영 향을 미치지는 못하였다(Fig. 3).

림프구 활성물질인 $\mathrm{PHA}$ 로 말초혈액 단핵구의 활성화를 유도한 경우 음성대조군에 비해 $\mathrm{TNF}-\alpha, \mathrm{IL}-5, \mathrm{INF}-\gamma$ 모두 생성이 증가하였으며, $\mathrm{PHA}$ 에 의한 $\mathrm{INF}^{-} \gamma$ 의 생성이 배양 48 시간과 72 시간에 편백정유의 농도 증가에 따라 유의하게 억 제됨을 확인할 수 있었다. $\mathrm{PHA}$ 에 의한 $\mathrm{TNF}-\alpha$ 와 IL-5의 생 성은 $0.2 \%$ 의 편백정유로 처리한 경우에만 생성 억제되는 경 향을 보였으나 통계적 유의성을 보이지는 않았다(Fig. 4).

\section{고 찰}

식물과 나무정유는 오래전부터 인간의 질병 치료를 위한 민 간요법으로 사용되어 왔다. 다양한 나무정유들이 cyclooxygenase-2 등의 활성화 억제를 통해 항염증 효과를 가지는 것으 로 알려져 있고, LPS에 의한 prostaglandin E2의 생성 또한 편백정유에 의해 억제되었으며, 기관지 천식 생쥐모델의 호흡 기 과민반응을 억제하는 항염증 효과에 대해서도 알려져 있 다. ${ }^{15,16)}$ 하지만 나무정유의 경우 나무의 종류, 나무가 자라는 지역, 나무정유 채취 시기 등에 따라 그 성분의 차이가 있을 수 있어 나무정유의 성분이 일정하여야 한다. 본 연구에서 사용한 편백정유의 경우 나무의 잔가지와 잎을 1 년간 채취하 여 계절에 따른 성분 차이를 해결할 수 있었으며, 정유 채취 후 약 12 개월간의 안정기를 거처 추출 과정에서 발생하는 나 무정유 특성의 변화를 최소화하였다. 또한 나무정유는 각종 해충, 곰팡이, 박테리아 등으로부터 나무를 보호하는 역할을 하기 때문에 인체에 적용하는 경우, 경우에 따라 독성이 나타 나 인체에 악영향을 끼칠 수 있다. $1 \%$ 이상의 편백정유로 말 초혈액 단핵구를 처리한 경우 세포분화가 급격히 감소함을 확 인할 수 있었고, 비교적 안전한 $0.2 \%$ 이하의 농도에서 항염증 효과를 확인하고자 하였다.

편백정유의 경우 약 68가지의 구성성분( $\alpha$-terpinyl acetate $13.78 \%$, sabinene $13.6 \%$, bornyl acetate $10.9 \%$ 등)으로 이루 어진 복합체로 테르펜(terepene)이라는 휘발성 유기화합물에 의해 정유의 고유한 향기를 가진다. ${ }^{17)}$ 편백정유는 자연살세 포의 활동을 증진시키고, 스트레스와 긴장을 완화시켜주는 등 인체 면역기전에 영향을 미치며, 그람 양성균과 그람 음성 균에 대한 항균효과뿐 아니라 항진균제의 특성을 가지고 있 다. ${ }^{8,9,16,18,19)}$ 하지만 편백정유의 알레르기 및 감염성 염증반응 을 조절하는 말초혈액 단핵구 활성화 억제효과에 대한 보고 
는 많다. 본 연구는 세균 독소인 LPS와 세포증식 유도물질인 $\mathrm{PHA}$ 로 말초혈액 단핵구의 활성화를 유도하였으며 화학매개 물질 생성 억제 여부를 확인함으로써 편백정유의 항염증 효 과를 확인하고자 하였다. LPS는 감염성 염증반응 물질인 $\mathrm{TNF}-\alpha$ 와 Th1 사이토카인인 INF- $\gamma$ 을 증가시키고, PHA는 염증성 화학매개물질 모두를 증가시킬 수 있다. LPS에 의한 $\mathrm{TNF}^{-} \alpha$ 의 생성은 편백정유의 농도 증가에 따라 유의하게 생성 이 억제되었으며, INF- $\gamma$ 는 편백정유 $0.1 \%(77.8 ~ 85.7 \%)$ 와 $0.2 \%$ (68.9 95.6\%)에서 강력하게 억제되었다. PHA에 의한 $\mathrm{INF}^{-\gamma} \gamma$ 의 생성은 편백정유의 농도 증가에 따라 유의하게 생성이 억 제되었으며, $\mathrm{TNF}-\alpha$ 의 경우 배양 48 시간(25.7\%)과 72시간 (30.0\%)에 편백정유 $0.2 \%$ 에서, IL-5의 경우는 배양 72 시간 (33.2\%)에 편백정유 $0.2 \%$ 에서 생성이 억제되는 경향을 보였으 나 통계학적 의미는 없었다. 하지만 말초혈액 단핵구 활성화 유 도 물질 없이 편백정유로 처리한 경우 $\mathrm{TNF}-\alpha, \mathrm{INF}-\gamma, \mathrm{IL}-5$ 의 생성이 낮은 농도인 $0.05 \%$ 의 편백정유에 의해 증가되었다. 이는 편백정유가 염증성 환경에서는 항염증 효과를 나타내 지만 편백정유 자체도 면역세포의 활성화를 유도할 수 있음 을 의미할 것이다. 이는 멜라루카 정유의 자연살세포 활성화 를 유도하는 효과와 유사한 현상일 것이다. ${ }^{20)}$ 본 연구에서는 편백정유의 항염증 효과는 말초혈액 단핵구의 $\mathrm{TNF}-\alpha$ 와 $\mathrm{INF}-\gamma$ 생성을 억제함을 확인하였으나 IL-5에는 영향을 미치 지 않아 집먼지 진드기와 같은 알레르기 유발물질에 대한 항 염증반응은 확인하지 못하였다. 또한 편백정유의 항염증 기 전을 확인하지 않은 제한점을 가지고 있다. 기존 연구에 따르 면 나무정유 항염증 효과는 항산화 작용 및 활성산소의 생성 억제와 cyclooxygenase 경로의 차단 등이 관여하는 것으로 알 려져 있다. ${ }^{3,16,19)}$ 편백정유는 40 여 종의 화학물질로 구성되어 있는데 이들 성분 중 어떤 물질이 항염증, 항균, 항진균 등의 특성을 나타내는지에 대한 추가적인 연구가 필요할 것으로 생 각된다.

이상의 결과를 종합해 보면 편백정유는 말초혈액 단핵구 에 대한 면역 활성화에 영향을 미칠 뿐 아니라 말초혈액 단핵 구에서 만들어지는 염증성 화학매개물질의 생성을 억제할 수 있음을 확인하였다. 편백정유의 항염증 효과는 향후 인체의 염증성 질환 치료제로의 개발 가능성을 확인할 수 있는 결과 로 다양한 염증질환 모델을 이용한 연구가 필요할 것이다.

\section{Acknowledgments}

This research was supported by Basic Science Research Program through the National Research Foundation of Korea (NRF) funded by the Ministry of Education (2016R1D1A1B03931622).

\section{REFERENCES}

1) Abe T, Hisama M, Tanimoto $S$, Shibayama H, Mihara Y, Nomura
M. Antioxidant effects and antimicrobial activites of phytoncide. Biocontrol Sci 2008;13(1):23-7.

2) Kang S, Lee JS, Lee HC, Petriello MC, Kim BY, Do JT, et al. Phytoncide extracted from pinecone decreases LPS-induced inflammatory responses in bovine mammary epithelial cells. J Microbiol Biotechnol 2016; 26(3):579-87.

3) Fujimori H, Hisama M, Shibayama H, Iwaki M. Protecting effect of phytoncide solution, on normal human dermal fibroblasts against reactive oxygen species. J Oleo Sci 2009;58(8):429-36.

4) Reis D, Jones T. Aromatherapy: using essential oils as a supportive therapy. Clin J Oncol Nurs 2017;21(1):16-9.

5) Tu PT, Tawata S. Anti-oxidant, anti-aging, and anti-melanogenic properties of the essential oils from two varieties of Alpinia zerumbet. Molecules 2015;20(9):16723-40.

6) Kang SK, Shin MK, Auh QS, Chun YH, Hong JP. Antibacterial effect on oral pathogenic bacteria of phytoncide from Chamaecyparis obtusa. J Oral Med Pain 2007;32(1):45-55.

7) Jung JY, Kim HS, Kim KR. Studies on antioxidative and antimicrobial activity from Hinoki Cypress oil. J Investig Cosmetol 2010;6(4): 407-17.

8) Ahn JY, Lee SS, Kang HY. Biological activities of essential oil from Chamaecyparis obtusa. J Soc Coset Scientist Korea 2004;30(4): 503-7.

9) Kang SK, Auh QS, Chun YH, Hong JP. Effect of Chamaecyparis obtusa tree phytoncide on Candida albicans. J Oral Med Pain 2010;35(1): 19-29.

10) Passos GF, Fernandes ES, da Cunha FM, Ferreira J, Pianowski LF, Campos MM, et al. Anti-inflammatory and anti-allergic properties of the essential oil and active compounds from Cordia verbenacea. J Ethnopharmacol 2007;110(2):323-33

11) Fernandes ES, Passos GF, Medeiros R, da Cunha FM, Ferreira J, Campos MM, et al. Anti-inflammatory effects of compounds alphahumulene and (-)-trans-caryophyllene isolated from the essential oil of Cordia verbenacea. Eur J Pharmacol 2007;569(3):228-36.

12) Pellerin $L$, Jenks JA, Bégin $P$, Bacchetta R, Nadeau KC. Regulatory $T$ cells and their roles in immune dysregulation and allergy. Immunol Res 2014;58(2-3):358-68.

13) Kim SK, Lee SM, Lim HB. Attenuation effect of Chamaecyparis obtusa leaf essential oils on airway hyperresponsiveness and airway inflammation in ovalbumin-induced murine asthma model. Korean J Med Crop Sci 2015;23(3):237-44.

14) An BS, Kang JH, Yang H, Jung EM, Kang HS, Choi IG, et al. Antiinflammatory effects of essential oils from Chamaecyparis obtusa via the cyclooxygenase-2 pathway in rats. Mol Med Rep 2013;8(1): 255-9.

15) Lim GS, Kim R, Cho H, Moon YS, Choi CN. Comparison of volatile compounds of Chamaecyparis obtusa essential oil and its application on the improvement of atopic dermatitis. KSBB J 2013;28(2):115-22.

16) Li Q, Kobayashi M, Wakayama Y, Inagaki H, Katsumata M, Hirata $\mathrm{Y}$, et al. Effect of phytoncide from trees on human natural killer cell function. Int J Immunopathol Pharmacol 2009;22(4):951-9.

17) Li Q, Kawada T. Effect of forest environments on human natural killer (NK) activity. Int J Immunopathol Pharmacol 2011;24(1 Suppl): 39S-44S.

18) Lima DK, Ballico LJ, Rocha Lapa F, Gonçalves HP, de Souza LM, Iacomini M, et al. Evaluation of the antinociceptive, anti-inflammatory and gastric antiulcer activities of the essential oil from Piper aleyreanum C. DC in rodents. J Ethnopharmacol 2012;142(1):274-82.

19) Chou ST, Peng HY, Hsu JC, Lin CC, Shih Y. Achillea millefolium L. essential oil inhibits LPS-induced oxidative stress and nitric oxide production in RAW 264.7 Macrophages. Int J Mol Sci 2013;14(7): 12978-93.

20) Caldefie-Chézet F, Fusillier C, Jarde T, Laroye H, Damez M, Vasson MP, et al. Potential anti-inflammatory effects of Melaleuca alternifolia essential oil on human peripheral blood leukocytes. Phytother Res 2006;20(5):364-70. 